\title{
Pengaruh Kebiasaan Buang Air Besar (BAB) terhadap Kejadian Demam Tifoid di RSUD Al-Ihsan Bandung Periode Maret-Mei Tahun 2018

\author{
Melvi Imelia Risa, ${ }^{1}$ Ismawati, ${ }^{2}$ Budiman, ${ }^{3}$ Hana Sofia, ${ }^{4}$ Herry Garna ${ }^{5}$ \\ ${ }^{1}$ Program Studi Pendidikan Dokter, ${ }^{2}$ Bagian Parasitologi, Universitas Islam Bandung \\ ${ }^{3}$ Bagian Ilmu Kesehatan Masyarakat, Universitas Islam Bandung, ${ }^{4}$ Bagian Ilmu Kesehatan Anak, RSUD Al-Ihsan \\ Bandung, ${ }^{5}$ Fakultas Kedokteran, Universitas Islam Bandung
}

\begin{abstract}
Abstrak
Demam tifoid adalah penyakit endemik yang banyak terjadi di negara berkembang yang disebabkan oleh bakteri Salmonella typhi. Faktor risiko demam tifoid di antaranya usia, jenis kelamin, pendidikan, status sosial ekonomi, kebiasaan cuci tangan, serta kebiasaan buang air besar (BAB) di jamban. Dinas Kesehatan Kabupaten Bandung mencatat bahwa masyarakat Baleendah masih belum memiliki dukungan infrastruktur sanitasi yang baik seperti jamban serta kesadaran masyarakat yang rendah untuk melakukan pola hidup bersih yang berperan terhadap kejadian demam tifoid. Tujuan penelitian mengetahui hubungan kebiasaan cuci tangan dan buang air besar (BAB) dengan kejadian demam tifoid di RSUD Al-Ihsan periode Maret-Mei tahun 2018. Penelitian yang digunakan merupakan penelitian observasional analitik dengan menggunakan desain kasus kontrol dan pendekatan kuantitatif. Teknik pengambilan sampel dilakukan dengan purposive sampling, yaitu peneliti mengambil 50 sampel kasus dan kontrol yang dipilih sesuai dengan kriteria inklusi (anak usia $\geq 6$ tahun terdiagnosis probable demam tifoid) dan tidak termasuk kriteria eksklusi (anak dengan komplikasi berat). Data yang diperoleh menggunakan uji chi-square. Berdasar atas hasil perhitungan risk estimate kebiasaan buang air besar (BAB) diperoleh OR 4,55 (OR $>1$ ) nilai p <0,001 (IK 95\%: 1,69-12,79) serta nilai p cuci tangan o,06 (IK 95\%: 0,82-11,13) dengan risk estimate $2,82$. Simpulan terdapat pengaruh kebiasaan buang air besar (BAB) terhadap kejadian demam tifoid.
\end{abstract}

Kata kunci: Buang air besar, demam tifoid, higiene perseorangan

\section{Impact of Defecation Habits on the Incidence Typhoid Fever at Al-Ihsan General Hospital Bandung from March-May 2018}

\begin{abstract}
Typhoid fever is a common endemic disease in developing countries caused by Salmonella typhi bacteria. Risk factors of typhoid fever include age, sex, education, socioeconomic status, hand washing habits, and bowel habits in the toilet. Bandung District Health Office noted that Baleendah people still do not have the support of good sanitation infrastructure such as latrines and low awareness of the community to perform a clean lifestyle that plays a role against the incidence of typhoid fever. The objective of the study was to know the relationship between handwashing and defecation habit with the occurrence of typhoid fever in Al-Ihsan Hospital period March-May 2018. This research was an observational analytic study using case control design and quantitative approach. The sampling technique was done by purposive sampling, that is the researcher took 50 cases and control samples selected according to the inclusion criteria (age $\geq 6$ years and probable typhoid fever) and exclusion criteria (severe complications). The data obtained using chi-square test. Based on the result of calculation of risk estimate of bowel habit obtained OR 4.55 (OR> 1) p value <0.001 (CI 95\%: 1.69-12.79) and hand washing p value 0.06 (CI 95\%: o.82-11.13) with risk estimate 2.82. In conclusion there is an impact of defecation on with the incidence of typhoid fever.
\end{abstract}

Key words: Defecation habits, personal hygiene, typhoid fever 


\section{Pendahuluan}

Salah satu penyakit menular yang terus menjadi masalah kesehatan masyarakat yang serius di banyak negara berkembang adalah demam tifoid. ${ }^{1}$ Demam tifoid adalah infeksi sistemik yang disebabkan bakteri jenis Salmonella enterica serotype Typhi (S. typhi). Penyakit ini masih merupakan masalah kesehatan masyarakat yang penting terutama di negara-negara berkembang. ${ }^{2}$ Di Indonesia, orang berusia 3-19 tahun menyumbang $91 \%$ kasus demam tifoid. ${ }^{3}$ Salmonella typhi adalah bakteri yang hidup hanya pada manusia. ${ }^{4}$ Infeksi salmonella tersering melalui rute oral biasanya diakibatkan oleh konsumsi makanan atau air yang terkontaminasi. ${ }^{5}$

Higiene perseorangan merupakan faktor berisiko terjadi demam tifoid. Kebersihan yang baik merupakan intervensi yang penting bagi banyak penyakit menular. Hal tersebut dapat dilaksanakan dengan beberapa cara di antaranya mencuci tangan mempergunakan sabun setelah buang air besar dan sebelum makan. ${ }^{6}$ Selain itu, faktor risiko demam tifoid lainnya meliputi usia, jenis kelamin, pendidikan, status sosial ekonomi, kebiasaan cuci tangan, serta kebiasaan buang air besar (BAB) di jamban.?

Berdasar atas data Dinas Kesehatan Kabupaten Bandung, cakupan masyarakat yang sudah mempunyai jamban pribadi sekitar $89 \%$, tetapi sekitar $66,7 \%$ di antaranya pembuangan limbah dari jamban tersebut ke kebun atau ke dalam sungai. Dukungan infrastruktur sanitasi yang kurang dan kesadaran masyarakat yang rendah untuk melakukan pola hidup bersih berperan terhadap kualitas dan kuantitas sanitasi yang rendah. Tingkat kesehatan masyarakat menurun dan beberapa penyakit dapat terjadi akibat sanitasi yang kurang baik salah satunya demam tifoid. ${ }^{8}$

Kelurahan Baleendah mempunyai sanitasi yang kurang baik dan juga merupakan wilayah yang paling padat dari seluruh Kecamatan Baleendah. Menurut studi Environmental Health Risk Assessment (EHRA) tingkat kepadatan yang tinggi berpengaruh terhadap jumlah penduduk miskin. Di Kelurahan Baleendah ini jumlah penduduk miskin digolongkan dalam kategori sangat tinggi serta akses terhadap jamban pribadi tergolong masih rendah. Hal tersebut berpengaruh terhadap risiko sanitasi terhadap masyarakat. ${ }^{8}$ Tujuan melakukan penelitian ini adalah mengetahui hubungan higiene perseorangan dengan kejadian demam tifoid di RSUD Al-Ihsan Bandung pada periode Maret-Mei tahun 2018.

\section{Metode}

Metode penelitian ini adalah observasional analitik mempergunakan desain kasus kontrol. Pemilihan subjek penelitian dengan purposive sampling yang diambil menggunakan kuesioner dan wawancara pada pasien anak penderita demam tifoid di Ruang Anak Lukmanul Hakim RSUD Al-Ihsan Bandung periode Maret-Mei 2018 dan pada anak sehat yang memenuhi kriteria inklusi sebagai kontrol. Kriteria inklusi pada penelitian ini pasien terdiagnosis probable demam tifoid yang dirawat inap berusia $\geq 6$ tahun dan anak sehat yang berdomisili di lingkungan Baleendah yang berusia $\geq 6$ tahun sebagai kontrol. Kriteria eksklusi pada penelitian ini adalah pasien dengan komplikasi berat (penurunan kesadaran) dan pasien yang tidak diperiksa secara lengkap.

Higiene perseorangan adalah perilaku menjaga tubuh agar tetap bersih dan juga membantu mencegah penyebaran kuman banyak penyakit menular. Perilaku higienis yang dikumpulkan dalam penelitian meliputi perilaku buang air besar (BAB) dan perilaku mencuci tangan. Mencuci tangan dikatakan baik bila subjek mencuci tangan dengan sabun sebelum menyiapkan makanan, pada setiap kali tangan kotor, dan setelah buang air besar, tetapi jika ketiga komponen tersebut tidak terpenuhi maka dikatakan buruk. Perilaku BAB yang dianggap baik adalah bila subjek melakukannya di jamban, selain itu dikategorikan buruk. Penelitian ini sudah mendapat persetujuan dari Komite Etik Penelitian Kesehatan Fakultas Kedokteran Universitas Islam Bandung Nomor: 244/Komite Etik.FK/III/2018.

\section{Hasil}

Hasil penelitian yang dilaksanakan di Ruang Anak Lukmanul Hakim RSUD Al-Ihsan Bandung periode Maret-Mei 2018 terdapat 154 orang penderita demam tifoid yang dirawat, sedangkan subjek yang termasuk dalam kriteria inklusi diambil sebanyak 50 orang penderita dan 50 anak sehat.

Tabel 1 Karakteristik Subjek Penelitian

\begin{tabular}{|c|c|c|c|c|c|c|}
\hline \multirow{2}{*}{$\begin{array}{c}\text { Karakteristik } \\
\text { Subjek }\end{array}$} & \multicolumn{2}{|c|}{ Kontrol } & \multicolumn{2}{|c|}{ Kasus } & \multicolumn{2}{|c|}{ Total } \\
\hline & $\begin{array}{c}n \\
(50)\end{array}$ & $\%$ & $\begin{array}{c}\mathrm{n} \\
(\mathbf{5 0})\end{array}$ & $\%$ & $\begin{array}{c}n \\
(100)\end{array}$ & $\%$ \\
\hline \multicolumn{7}{|l|}{ Usia (tahun) } \\
\hline $6-10$ & 36 & 72 & 37 & 74 & 73 & 73 \\
\hline $11-13$ & 14 & 28 & 13 & 26 & 27 & 27 \\
\hline \multicolumn{7}{|l|}{ Jenis kelamin } \\
\hline Perempuan & 30 & 60 & 31 & 62 & 61 & 61 \\
\hline Laki-laki & 20 & 40 & 19 & 38 & 39 & 39 \\
\hline \multicolumn{7}{|l|}{ Pendidikan } \\
\hline SD & 37 & 74 & 38 & 76 & 75 & 75 \\
\hline SMP & 13 & 26 & 12 & 24 & 25 & 25 \\
\hline
\end{tabular}

Dalam kelompok kasus dan kontrol sama-sama memiliki jumlah subjek berusia 6-10 tahun sebagai kelompok terbanyak, berjenis kelamin perempuan, dan mayoritas berpendidikan SD. Jumlah seluruh subjek 100 orang dengan proporsi kasus kontrol 50/50.

Risk estimate diperoleh OR 4,55 (OR>1) dengan (IK 95\%: 1,69-12,79) pada kelompok yang memiliki kebiasaan $\mathrm{BAB}$ buruk, berarti subjek yang memiliki kebiasaan $\mathrm{BAB}$ yang buruk memiliki risiko 4,55 kali lebih besar jika dibanding dengan subjek yang memiliki kebiasaan buang air besar (BAB) yang baik. Berbeda dengan kebiasaan cuci tangan yang tidak mempunyai hubungan signifikan terhadap kejadian demam tifoid. Tetapi, pada kelompok yang memiliki kebiasaan cuci tangan buruk, odds untuk mengalami demam tifoid lebih besar 2,82 (IK 95\%: 0,82-11,13) bila dibanding dengan kelompok yang memiliki kebiasaan mencuci tangan dengan baik. 
Tabel 2 Hubungan Kebiasaan BAB dan Cuci Tangan dengan Kejadian Demam Tifoid

\begin{tabular}{|c|c|c|c|c|c|}
\hline \multirow[b]{2}{*}{$\begin{array}{l}\text { BAB } \\
\text { dan Cuci } \\
\text { Tangan }\end{array}$} & \multicolumn{2}{|c|}{ Demam Tifoid } & \multirow[b]{2}{*}{ OR } & \multirow[b]{2}{*}{$\underset{95 \%}{\text { IK }}$} & \multirow[b]{2}{*}{ p } \\
\hline & $\begin{array}{l}\text { Positif } \\
\text { n (\%) }\end{array}$ & $\begin{array}{c}\text { Negatif } \\
\text { n }(\%)\end{array}$ & & & \\
\hline \multicolumn{6}{|l|}{ BAB } \\
\hline Buruk & $25(50 \%)$ & $9(18 \%)$ & \multirow{2}{*}{4,55} & \multirow{2}{*}{$\begin{array}{l}1,69- \\
12,79\end{array}$} & \multirow{2}{*}{$<0,001$} \\
\hline Baik & $25(50 \%)$ & $41(82 \%)$ & & & \\
\hline \multicolumn{6}{|c|}{ Cuci tangan } \\
\hline Buruk & $45(90 \%)$ & $38(76 \%)$ & \multirow{2}{*}{2,82} & \multirow{2}{*}{$\begin{array}{l}0,82- \\
11,13\end{array}$} & \multirow{2}{*}{0,06} \\
\hline Baik & $5(10 \%)$ & $12(24 \%)$ & & & \\
\hline Total & $50(100 \%)$ & $50(100 \%)$ & & & \\
\hline
\end{tabular}

Keterangan: analisis bivariat

Tabel 3 Hubungan Kebiasaan BAB dan Cuci Tangan dengan Demam Tifoid

\begin{tabular}{lcccc}
\hline Tifoid & Koefisien & $\mathbf{p ~ ( z )}$ & $\mathbf{p ~ ( c h i ~ s q )}$ & Pseudo R sq \\
\hline BAB & 1,41 & 0,00 & & \\
Cuci tangan & 0,73 & 0,23 & 0,00 & 0,09 \\
Konstanta & $-1,07$ & 0,05 & & \\
Keterangan: analisis multivariat
\end{tabular}

Koefisien positif yang dimiliki variabel $\mathrm{BAB}$ dan cuci tangan menunjukkan peningkatan odds untuk mengalami demam tifoid apabila memiliki kebiasaan $\mathrm{BAB}$ dan cuci tangan buruk. Variabel $\mathrm{BAB}$ dan cuci tangan memengaruhi $9 \%(0,09)$ variasi terjadinya demam tifoid secara signifikan $(\mathrm{p}<0,05)$.

\section{Pembahasan}

Hasil penelitian ini angka kejadian demam tifoid paling tinggi pada masa kanak-kanak, yaitu pada usia 6-10 tahun karena pada usia tersebut cenderung memiliki aktivitas fisik yang banyak dan tidak memperhatikan pola makannya, akibatnya anak cenderung akan lebih memilih makan di luar rumah atau jajan di tempat yang lain. Bakteri Salmonella typhi itu banyak berkembang biak khususnya dalam makanan yang higienitasnya kurang terjaga..$^{9,10}$

Hasil analisis untuk jenis kelamin memperlihatkan bahwa jumlah subjek yang paling banyak mengalami demam tifoid adalah perempuan. Keadaan ini berbeda dengan penelitian yang dilakukan oleh Pramitasari dan Purnia ${ }^{11}$ bahwa laki jauh lebih berisiko mengalami demam tifoid bilamana dibanding dengan perempuan karena laki mempunyai aktivitas yang lebih tinggi daripada perempuan. Keadaan ini dapat terjadi karena sebagian besar subjek yang diambil berdasar atas data dari ruangan anak Lukmanul Hakim RSUD Al-Ihsan Bandung merupakan data dari responden perempuan, namun tidak menutup kemungkinan bahwa penderita demam tifoid laki juga mempunyai angka kejadian yang tinggi. ${ }^{11}$ Pada penelitian ini sejalan dengan penelitian yang dilakukan oleh Vollard dkk. ${ }^{7}$ di Jakarta bahwa perempuan lebih berisiko mengalami demam tifoid karena sering jajan di pinggir jalan dan mengonsumsi minuman dari air yang tidak matang. Selanjutnya, dari hasil penelitian yang diperoleh terhadap karakteristik pendidikan subjek menunjukkan bahwa jumlah subjek yang paling banyak adalah subjek dengan pendidikan SD dibanding dengan SMP. Hal tersebut karena subjek dengan pendidikan SD belum banyak mengetahui informasi mengenai kesehatan serta kesadaran diri yang masih rendah. Faktor pendidikan diperlukan untuk mendapatkan informasi seperti hal-hal yang menunjang kesehatan sehingga dapat meningkatkan kualitas hidup. ${ }^{12}$ Buang air besar (BAB) merupakan salah satu indikator dari perilaku higiene dan dianggap benar atau baik bila subjek melakukannya di jamban, selain itu maka dikategorikan buruk. ${ }^{13}$

Dari hasil uji chi-square diperoleh nilai $\mathrm{p}=0,00$ yang berarti terdapat hubungan kebiasaan $\mathrm{BAB}$ dan kejadian demam tifoid di RSUD Al-Ihsan Bandung. Perhitungan risk estimate diperoleh nilai OR 4,55 (OR>1) dengan (IK 95\%: 1,69-12,79), hal tersebut menunjukkan bahwa subjek yang memiliki kebiasaan $\mathrm{BAB}$ yang buruk memiliki risiko 4,55 kali lebih besar jika dibanding dengan subjek yang memiliki kebiasaan $\mathrm{BAB}$ yang baik.

Hasil penelitian yang dilakukan saat wawancara diperoleh hasil sebagian besar subjek sudah melakukan kebiasaan $\mathrm{BAB}$ di jamban, tetapi tidak sedikit juga yang memiliki kebiasaan $\mathrm{BAB}$ di tempat lain seperti kolam, sungai, atau tempat pembuangan tinja di luar rumah yang dipakai bersamaan oleh beberapa penghuni rumah yang dibuang melalui sungai. Dukungan infrastruktur sanitasi yang kurang dan kesadaran masyarakat yang rendah untuk melakukan pola hidup bersih berperan terhadap kualitas dan kuantitas sanitasi yang rendah. Hal tersebut berpengaruh terhadap risiko sanitasi pada masyarakat untuk meningkatkan risiko terjadinya demam tifoid. ${ }^{8}$

Salah satu indikator dari PHBS itu adalah BAB menggunakan jamban sehat. Jamban adalah ruangan yang mempunyai fasilitas untuk pembuangan kotoran manusia yang dilengkapi dengan unit penampungan kotoran dan juga air untuk membersihkannya. Setiap anggota rumah tangga harus menggunakan jamban untuk BAB maupun BAK. Pentingnya menggunakan jamban itu untuk menjaga lingkungan bersih, sehat, tidak berbau, tidak mencemari air yang berada di sekitarnya, serta mencegah penularan penyakit seperti diare dan demam tifoid..$^{14,15}$

Penularan penyakit demam tifoid bersifat fekaloral sehingga pembuangan kotoran melalui jamban menjadi penting. Penggunaan jamban keluarga dengan baik dan juga bersih dapat mengurangi risiko terjadi demam tifoid. ${ }^{14,16} \mathrm{Hal}$ ini sama dengan penelitian yang dilakukan oleh Kurniasih ${ }^{17}$ diperoleh bahwa terdapat hubungan antara sanitasi lingkungan dan kejadian demam tifoid di wilayah kerja Rumah Sakit Jasa Kartini Tasikmalaya. Sanitasi lingkungan yang buruk seperti tidak tersedia jamban dan sarana air bersih yang memenuhi syarat merupakan salah satu faktor risiko terjadi demam tifoid.

Pada kebiasaan cuci tangan diperoleh nilai $p$ cuci tangan mendekati signifikansi yang ditentukan 
( $a=0,05)$ sehingga tidak dianggap terdapat hubungan yang signifikan secara statistik antara cuci tangan dan kejadian demam tifoid. Dalam teori perilaku mencuci tangan dengan air bersih dan sabun merupakan salah satu indikator yang terdapat dalam tatanan PHBS rumah tangga. Hal tersebut bermanfaat untuk membunuh kuman penyakit yang ada di tangan serta mencegah penularan penyakit seperti diare, kolera, disentri, demam tifoid, dan kecacingan. Penyebaran penyakit demam tifoid dapat terjadi melalui makanan atau minuman yang terkontaminasi oleh berbagai patogen. Tangan yang kotor mampu memindahkan bakteri yang patogen dari tangan ke dalam makanan sehingga bakteri akan masuk dan menginfeksi tubuh seseorang yang mengonsumsi makanan tersebut. ${ }^{14,}, 15$

Berdasar atas hasil analisis data diperoleh odds ratio 2,82. Hal tersebut menunjukkan bahwa subjek yang mempunyai kebiasaan cuci tangan yang buruk dapat mengalami demam tifoid 2,82 kali lebih besar dibanding dengan subjek yang memiliki kebiasaan mencuci tangan dengan baik. Berbeda dengan hasil penelitian yang dilakukan Malau dkk. ${ }^{18}$ di wilayah kerja Puskesmas Bandarharjo bahwa terdapat hubungan yang signifikan antara kebiasaan mencuci tangan pada anak dan kejadian demam tifoid dengan risk estimate sekitar 4,33.

Mencuci tangan dengan sabun adalah cara paling efektif untuk mencegah penularan beberapa organisme yang dapat menyebabkan penyakit menular. Mencuci tangan dilaksanakan setelah $\mathrm{BAB}$, juga sebelum dan sesudah makan, serta ketika tangan kotor. ${ }^{13}$ Berbeda juga dengan penelitian yang dilakukan oleh Seran dkk. ${ }^{19}$ di Tumaratas bahwa terdapat hubungan antara kebiasaan cuci tangan dan kejadian demam tifoid. Hal tersebut karena masih banyak faktor risiko lain yang dapat menyebabkan demam tifoid, di antaranya usia, jenis kelamin, status ekonomi, ukuran rumah, kepadatan penduduk, tidak memiliki jamban pribadi, jajan di pinggir jalan, berbagi makanan dari tempat yang sama, sumber airyang terkontaminasi, dan banjir. ${ }^{7}$ Hasil penelitian Vollard dkk.7 faktor risiko demam tifoid yang paling sering disebabkan oleh konsumsi makanan dari pedagang kaki lima dan sumber air yang terkontaminasi. Hal tersebut juga berhubungan dengan keadaan di lingkungan masyarakat Baleendah yang belum mempunyai kualitas dan kuantitas sanitasi yang cukup baik sehingga dapat mencemari air yang ada di sekitarnya dan meningkatkan kejadian demam tifoid. ${ }^{8,14,15}$

Berdasar atas hasil penelitian diperoleh koefisien positif yang dimiliki oleh variabel $\mathrm{BAB}$ dan cuci tangan menunjukkan peningkatan risk estimate untuk mengalami demam tifoid apabila seseorang memiliki kebiasaan $\mathrm{BAB}$ dan cuci tangan yang buruk. Variabel tersebut memengaruhi $9 \%(0,09)$ dari variasi kejadian demam tifoid secara signifikan.

Hal tersebut menunjukkan bahwa kebiasaan $\mathrm{BAB}$ dan cuci tangan merupakan faktor risiko demam tifoid. Namun, masih terdapat banyak faktor lain yang dapat menyebabkan demam tifoid. Faktor lain yang memengaruhi kejadian demam tifoid antara lain jenis kelamin, usia, status gizi, kebiasaan jajan, kebiasaan cuci tangan, pendidikan orangtua, tingkat penghasilan orangtua, pekerjaan orangtua, dan sumber air. ${ }^{7}$
Berdasar atas penelitian Vollard dkk. ${ }^{7}$ mengenai faktor risiko demam tifoid di Jakarta, faktor risiko yang berperan di antaranya usia, jenis kelamin, status sosial ekonomi, riwayat demam tifoid, mencuci tangan tidak menggunakan sabun, mengonsumsi makanan yang dijual di pinggir jalan, sanitasi air, dan banjir. Penelitian sebelumnya yang telah dilakukan oleh Alladany dkk. ${ }^{20}$ menunjukkan bahwa sanitasi lingkungan serta perilaku kesehatan merupakan faktor risiko kejadian demam tifoid. Selain itu, kualitas sumber air bersih, kualitas jamban keluarga, pengelolaan sampah rumah tangga, praktik kebersihan diri, serta pengelolaan makanan dan minuman rumah tangga juga merupakan faktor risiko demam tifoid. Keterbatasan penelitian belum dapat menentukan berapa lama pengaruh kebiasaan cuci tangan dan $\mathrm{BAB}$ memengaruhi kejadian demam tifoid, serta terdapat faktor risiko lain selain kebiasaan cuci tangan dan BAB terhadap demam tifoid yang tidak diteliti pada penelitian ini.

\section{Simpulan}

Simpulan, terdapat hubungan kebiasaan BAB dengan kejadian demam tifoid dan tidak terdapat hubungan cuci tangan dengan kejadian demam tifoid pada pasien yang dirawat di RSUD Al-Ihsan Bandung.

\section{Ucapan Terima Kasih}

Ucapan terima kasih dan juga penghargaan kepada subjek yang telah bersedia mengikuti penelitian ini.

\section{Daftar Pustaka}

1. Pasteur S, Smith G, Ochiai RL, Carbis R, Levine $\mathrm{M}$, Soendore T, dkk. Report of the meeting on typhoid fever, a neglected disease: towards a vaccine introduction policy. Typhoid Fever in Asia. 2007;1(1):1-37.

2. Ochiai RL, Acosta CJ, Danovaro-Holliday MC, Baiqing D, Bhattacharya SK, Agtini MD, dkk. A study of typhoid fever in five Asian countries: disease burden and implications controls. Bull WHO. (diunduh 12 Januari 2018). Tersedia dari: http://www.who.int/bulletin/ volumes/86/4/o6-03981/en/.

3. WHO. Background document: the diagnosis, treatment and prevention of typhoid fever. Commun Dis Surveill Response Vaccines Biol. 2003;1(1):2-48.

4. You W. Salmonella typhi. Oakl Ctry Michigan Health Div. 2014;8:1-2.

5. Zhang X-L, Jeza VT, Pan Q. Salmonella typhi: from a human pathogen to a vaccine vector. Cell Mol Immunol. 2008;5(2):91-7.

6. WHO. Healthy villages: a guide for communities and community health workers, chapter 8: personal, domestic and community hygiene. Lagos, Nigeria: WHO; 2002.

7. Vollard AM, Ali S, Ansten H, Widjaja S, Visser L, Dissel JT, dkk. Risk factor for typhoid fever in Jakarta, Indonesia. Am Med Association. 2014 
Juni;291(2):1-9.

8. Siddiq MZRA, Pirngadie BH, Nurwulandari FS. Sanitasi Kecamatan Baleendah, Kabupaten Bandung. E-journal Unpas. 2016 Jan;3(4):86174 .

9. Departemen Kesehatan Jawa Barat. Profil Kesehatan Provinsi Jawa Barat Tahun 2012. (diunduh 13 Februari 2018). Tersedia dari: http://www.depkes.go.id/resources/download/ profil/profil_kes_provinsi_2012/12_Profil_Kes. Prov.JawaBarat_2012.pdf.

10. Herawati MH, Ghany L. Hubungan faktor determinan dengan kejadian tifoid di Indonesia. Puslitbang Biomed. 2016 Des;1(19):2009.

11. Pramitasari. Purnia O. Faktor risiko kejadian demam tifoid pada penderita yang dirawat di Rumah Sakit Umum Daerah Ungaran. E-journal Undip. 2013 Feb;22(2):1-10.

12. Wawan A. Teori \& pengukuran pengetahuan, sikap dan perilaku manusia. Yogyakarta: Nuha Medika; 2011.

13. Riset Kesehatan Dasar. Kuesioner kesehatan masyarakat. Bandung: Depkes RI; 2013.

14. Departemen Kesehatan. Pusat promosi kesehatan panduan pembinaan dan penilaian perilaku hidup bersih dan sehat di rumah tangga. Jakarta: Depkes RI; 2011.

15. Departemen Kesehatan. 10 perilaku hidup bersih dan sehat di rumah tangga. Jakarta: Departemen Kesehatan RI; 2013.

16. Chiou CS, Wei HL, Mu JJ, Liao YS, Liang SY, Liao CH, dkk. Salmonella enterica serovar typhi variants in long-term carriers. J Clin Microbiol. 2013 Feb;51(2):669-72.

17. Kurniasih. Hubungan faktor risiko dengan kejadian demam tifoid di Rumah Sakit Jasa Kartini Tasikmalaya. JKKI. 2011 Sep;1(11):2015.

18. Malau VM, Budiyono, Yusniar. Hubungan hygiene perseorangan dan sanitasi makanan rumah tangga dengan kejadian demam tifoid pada anak usia 5-14 tahun di wilayah kerja puskesmas Bandarharjo Kota Semarang. E-journal Undip. 2015 Jun;3(1):589-98.

19. Seran ER, Palandeng H, Kallo V. The highest occurrence of typhoid fever in 2014. Epidemiol Infect. 2015 Jan;3(2):11-9.

20. Alladany N, Welong S, Ratag B, Bernadus J. Hubungan sanitasi lingkungan dan perilaku sehat terhadap kejadian demam tifoid di Kota Semarang. E-journal Undip. 2010 Des;1(1):1-6. 